\title{
Assessment of the Traits of Facilities Management Key Drivers in South-Western Nigerian Hotels
}

\author{
Olufemi Daniel Durodola ${ }^{1}$, Caleb Abiodun Ayedun ${ }^{1} \&$ Ibidunni Seun Onipede $^{2}$ \\ ${ }^{1}$ Department of Estate Management, School of Environmental Sciences, College of Science and Technology, \\ Covenant University, Ota, Nigeria \\ ${ }^{2}$ Department of Estate Management, Faculty of Environmental Sciences, University of Lagos, Lagos, Nigeria \\ Correspondence: Olufemi Daniel Durodola, Department of Estate Management, School of Environmental \\ Sciences, College of Science and Technology, Covenant University, P.M.B 1023, Ota, Ogun State, Nigeria. \\ E-mail: daniel.durodola@yahoo.com
}

Received: January 16, 2012 Accepted: May 7, 2012 Online Published: May 31, 2012

doi:10.5539/jms.v2n2p163 URL: http://dx.doi.org/10.5539/jms.v2n2p163

\begin{abstract}
A survey was conducted of probabilistically determined fifty-seven hotels of various 'stars' in South-Western geo-political zone of Nigeria to assess the traits of the General Managers (GMs) and Facilities' Managers (FMs) who are regarded as key facilities management drivers in hotel organizations. Data were collected from hotel organizations through their general managers and facilities/engineers/maintenance managers with the aid of questionnaires. A combination of stratified and cluster sampling techniques were used. Kothari's formula was adopted to determine the appropriate sample size while descriptive statistics, ranking and spearman correlation were used for data analysis. Covey's generated traits for effective people were used as baseline parameters for the assessment. It was found that the GMs and the FMs background, training and features in South-Western Nigerian hotels cannot be said to be poor or low in that they compared favorably with what obtains in advanced countries particularly United State of America. However, they lack international exposure. In terms of traits, using Covey's model as benchmark, the duo are below average managerially, lacking the dynamism and the pizzazz that are required to propel them along; and since they are responsible for facilities management implementation, it then implies that the objectives of the facilities management may be extremely hampered from being achieved. In essence, the exposure of the GMs and the FMs must be deliberately improved upon while the duo must as a matter of urgency cultivate the habit of learning how to be effective.
\end{abstract}

Keywords: facilities management, hotel, human traits, strategic management, sustainable development

\section{Introduction}

Arditi and Nawakorawit (1999), Nebel, et al (2002), Hayes and Ninemeier (2007) and Durodola and Oloyede (2011) variously identified maintenance management, property management, and facilities management as asset management styles prevalent in the hospitality industry, although at varying degrees. In addition, Durodola, Ajayi and Oloyede (2011) averred that hotels that adopt facilities management as asset management tool as against maintenance management or property management are more effective in service delivery. Nevertheless, maintenance management predominates in the running of hotels (Hassanain, Froese and Vanier 2003) while property management is used to a limited degree (Durodola and Oloyede, 2011); yet, no condemnation has been recorded about the tools which points to human dimension or environment problem within which the tools are being implemented.

Smith (2003) asserted that facilities management concerns people and places; people are generally both the single biggest cost and asset center for any business or organization and whether as employee, manager, management or customer, they influence the degree of success of any operation or organization. By implication therefore, the success of facilities management as asset management style in hotel setting is greatly influenced by its drivers which, in this case are the General Manager (GM) and the Facilities Manager (FM). The impact of the duo is influenced by their traits as asserted by Odusami (2001) and Covey (2004). Thus, it is essential to examine the traits of the General Managers (GMs) and Facilities Managers (FMs) that drive facilities management within hotel setting with a view to establishing the influence they wield in order to make facilities management an effective asset management tool. 
The hotel and hospitality industry is a major area of the Nigerian economy which should attract investigation of the traits of facilities management key drivers as property asset management tool. This industry is crucial to the growth and development of tourism as a foreign exchange earner for many nations. The hotel organizations are not immune to the influences of the economy and business cycles, so the difficulties that befall business in general during economic down-turns also affect them (Rutherford, 2002). The acclaimed benefits of facilities management in turning the fortune of organizations around for better would be weakened or unrealizable if the drivers themselves lack drive and initiative. According to Opaluwah (2005); Adewunmi and Ogunba (2006); Durodola, Ajayi and Oloyede (2011) the responsiveness of the Nigerian society to facilities management is extremely low particularly within the hotel sector; and it is imperative that all impediments to accelerated facilities management implementation be identified and removed if Nigerians are to enjoy the benefits associated with holistic application of facilities management.

With this background, the aim of this research is to examine the traits of facilities management key drivers in hotel sector of the South-Western Nigerian economy, namely the General Managers and the Facilities Managers. In order to achieve the aim, the paper is structured into five major segments namely introduction, literature review, the research method, result and discussion and finally conclusion and recommendations.

\section{Literature Review}

Rutherford (2002) examined the organization of hotels by tracing hotel organization development in the United States at the turn of the twentieth century. Basically, hotel organizations were built around the chef ("king" of the kitchen) and the "maitre d'hotel" or the master of the hotel, and over time the hotel organization structures changed with radical changes in management. The hotel organization structure was based on line and staff structure hierarchically organized with the GM at the top and assisted by the Executive Assistant Manager to whom reports the line managers consisting of the Rooms' Divisional Head, Personnel, Accounting, Marketing and Sales, Engineering, Purchasing, Food and Beverage heads. This had been buttressed by Hayes and Ninemeier (2007) in their review of the organization charts of small, large and mega hotels in America as shown in Figure 1. The Rutherford (2002) and Hayes and Ninemeier (2007) studies are factual in that they have identified people that matters in the running of the hotels.

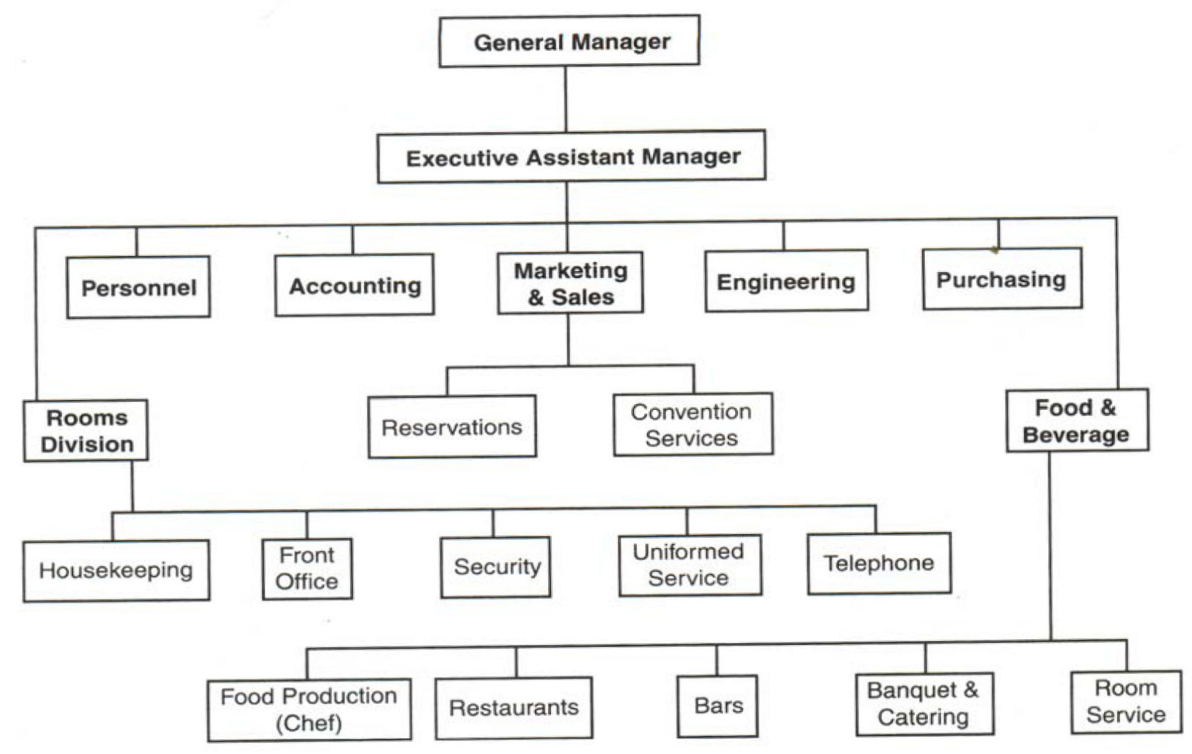

Figure 1. Typical hotel organization chart showing the GM's position and the line staff

Source: Rutherford (2002)

Eddystone and Nebel (2002)'s was more conservative than Rutherford (2002) in that they accepted the line and staff organization structure but seemingly overlooked the Engineering Department without suggesting an alternative to keep the facilities going and functional; while Conklin (2002) was more radical in approach by introducing the reverse organization chart as shown in Figure 2. The Conklin (2002)'s study is innovative and 
qualitative, emphasizing the need to take into cognizance three inter-related partners in the hotel running; which are, the customers, employees and the General Manager (GM). This has introduced the human dimension into the research activities involving facilities management and hotel organizations.

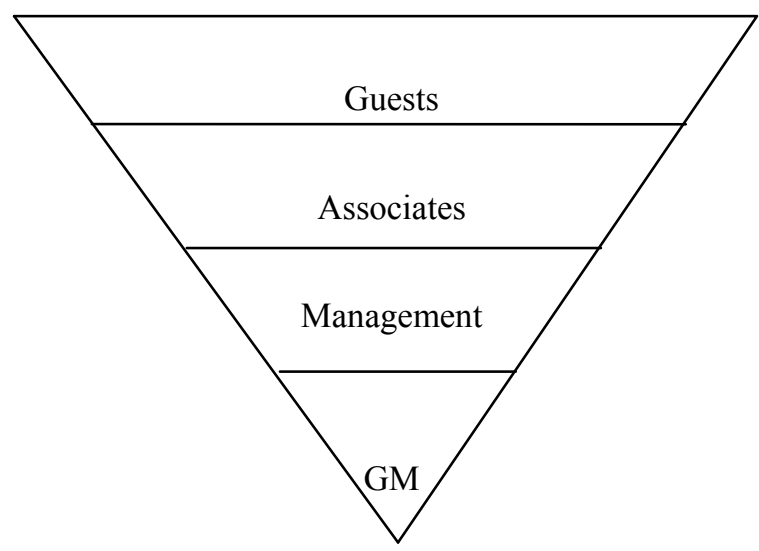

Figure 2. Reverse organization chart

Source: Conklin (2002)

Nebel and Ghei (2002) argued that hotel GM is the central management figure in the hotel business and attempted to develop a conceptual framework of the hotel General Manager's job based on job demands and relationship issues in the short-, intermediate- and long run. The aim of the study was to determine the nature of the GM's job, and consequently develop a conceptual framework. This was premised on the study of ten extremely successful GMs of some America's finest hotels that exhibited the fullest range of operational and managerial complexity. It adopted a combination of participant observation of GMs activities, extensive personal interviews of GMs and fifty-three key divisional heads, background surveys, and analysis of organizational and operational information from each hotel; and developed a model of the influences that shape the GM's job giving prominence to the GM of hotel organizations at the expense of the line managers, staff and customers as shown in Figure 3.

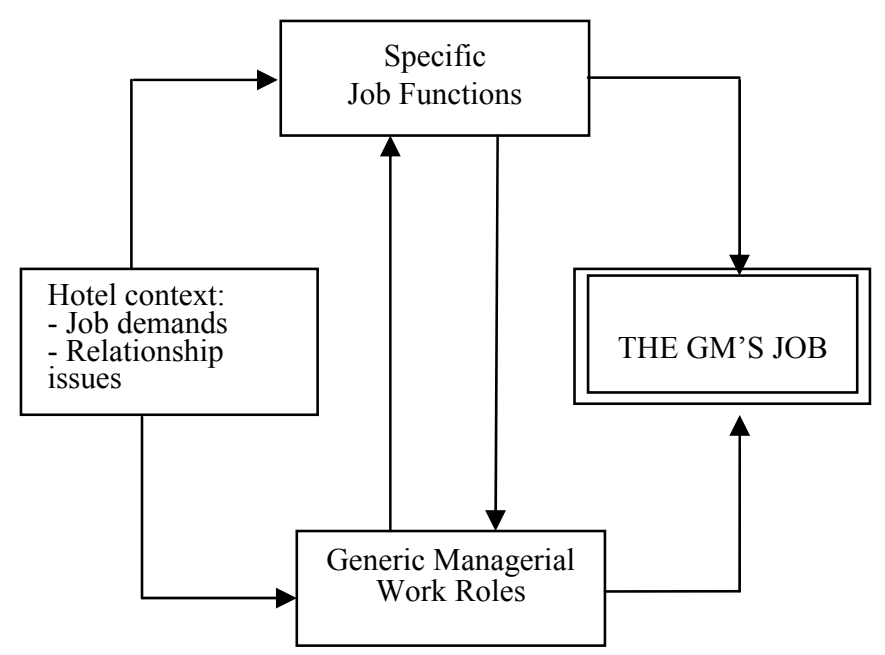

Figure 3. Influences that shape the general manager's job

Source: Nebel and Ghei (2002)

Nebel and Ghei (2002) asserted that for hotels' GMs to be effective at all three job functions (Operational Controller, Organizational Developer, and Business Maintainer) they are required to perform a large variety of 
managerial work roles. While GMs perform all ten of Mintzberg (1975)'s managerial work roles, they must be particularly effective at seven of them to be successful operational controllers, organizational developers, and business maintainers. They must develop the wide variety of skills necessary to play the work roles of leader, liaison, monitor, disseminator, disturbance handler, entrepreneur, and resource allocator.

Torkildsen (1992) asserted that quality management calls for quality managers; although good management counts, it may not necessarily and at all the times be the result of good general managers. However, it is obvious that hotels cannot function without the facilities working efficiently through the active participation of line managers in particular facilities manager or the engineer or maintenance manager whatever be the nomenclature that is assigned to him.

Hayes and Ninemeier (2007) corroborating Nebel and Ghei's (2002) opined that regardless of size, every hotel and lodging facility must have a leader that makes the final day- to- day decisions about how the facility operates. From the mega hotels to the smallest bed-and-breakfast (B and B), the individual is critical to the hotel's image, its reputation for guest service, and most importantly, its ultimate profitability. Although this person's job title may vary depending on the hotel's size, the traditional term variously being used is the General Manager (GM) and his responsibilities are inclusive of investor relations, brand affiliation management, community relations, executive committee facilitation, and property management. By and large, it is impossible to discuss or navigate hotel business operations without reviewing or talking about the GM whose traits are so important and crucial and must necessarily be investigated to ensure effectiveness in the service operations.

Woods, et al (2002) attested to the enviable position of the GMs by averring that researchers' focus on GMs was not without good reason and that no single position had greater effect on the success of a hotel facilities management. Their study focused on course of study, demographic profile, training requirements and compensation package among the GMs and adopted a survey research approach with participants randomly drawn from the American Hotel and Motel Association (AH \& HA) database using questionnaire and descriptive statistical techniques. It found that the average age of GMs was 46 years, major educational achievement been the bachelor's degree while the highest professional qualification was obtained from Chartered Hotel Association (CHA). Furthermore, although the management history is variable it includes years in lodging industry before first management job being 3.14 years; years from first management job to General Manager being 9.27 years; years as General Manager, 11.58 years; and 5.77 years in current GM position. The high point of the findings was that the GMs considered a strongly 'business-focused' curriculum to be most valuable for a person aspiring to GM's job.

Odusami (2001) opined that for ideal project leader, line and facilities managers to be effective, they require important skills and must possess desirable attributes, which are defined as 'quality ascribed to a particular thing' and regarded as inherent property. In this case, quality connotes distinguishing traits or characteristics and used interchangeably with attributes. The study posited that a project manager must possess the following qualities if he is to be effective: be proficient in his or her own discipline; have an appreciation of, and respect for all the involved disciplines; be as equally interested in the management of the project including schedule and budget control; possess excellent interpersonal skills; be committed to meeting the requirements of the hotel in terms of cost, time, quality and functionality; and possess ability to appreciate the environmental, economic, cultural and social concerns of the customers being served and the communities within which the hotel is operating.

These attributes had earlier been cited by Drucker (1972) as ingredients that an effective executive must possess. Drucker (1972) was of the opinion that it is essential to know what effective executive do that others fail to do and what they failed to do that others tend to do. The high point of the study was that effectiveness can be learned but also that it must be learned. It was also affirmed that effective executives are far from common and that the executive is first of all, expected to get the right things done. Even though high intelligence is common enough among executives, intelligence, imagination, and knowledge are essential attributes, which aid effectiveness in converting them to results. The argument in this study is succinct and points to the fact that highly effective chief executives and managers should possess sterling qualities that distinguishes them from the crowd and forms a yardstick for assessing managers.

Covey (2004) provides a platform for measuring the effectiveness of an Executive by identifying 'The Seven Habits of Highly Effective People" which are inclusive of being proactive, begin with the end in mind, putting first things first, think win-win, seeking first to understand than to be understood, synergizing and sharpening the saw in that order as shown in Figure 4. These habits are greatly influenced by knowledge, skill, and desire. This paradigm according to Covey (2004) is timeless and the greater the change in the society and the more difficult are the challenges which society faces, the more relevant the habits become. 


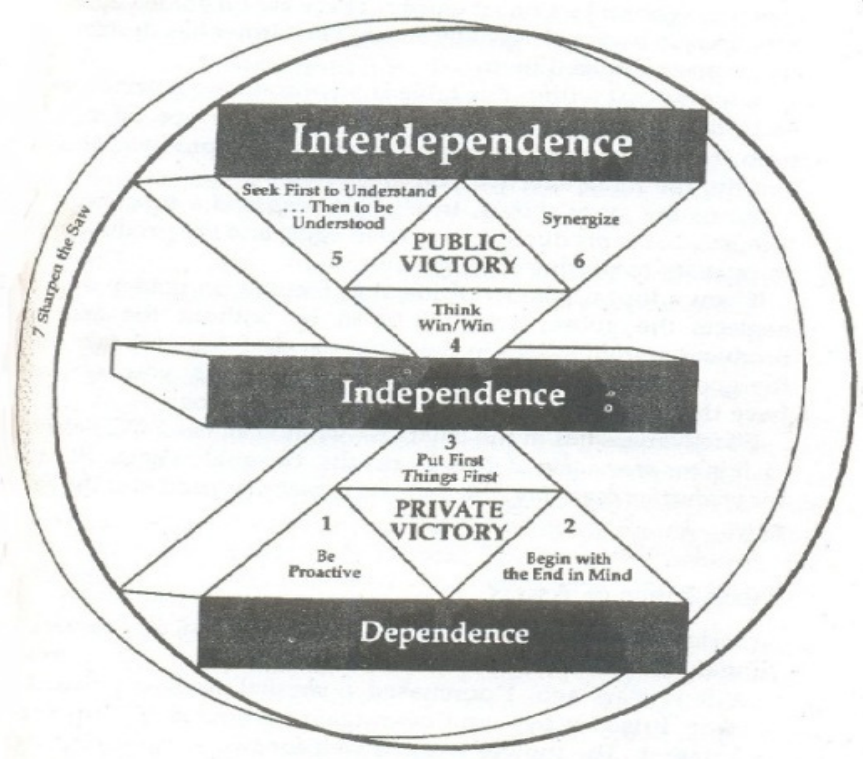

Figure 4. The seven habits paradigm

Source: Covey (2004)

Conklin (2002)'s radical view of hotel organization process and Nebel and Ghei's (2002) thoughts on the Hotel General Manager (GM) brought into the fore the importance of the contribution which the GM, the Line Managers, Facilities Manager, the Management and the Customers have to make to efficacious performance of facilities management in hotel organizations. The GM is the arrowhead of the establishment. He occupies the driver's seat and sees the horizon. Apart from enviable training, experience and exposure, such a person must be proactive, begin with the end in mind, put first things first, "think win-win" always, seek first to understand than to be understood, synergize and sharpen the saw in that order according to Covey (2004).

The facilities manager must have the same peculiar characteristics with the GM to be able to drive the vision and the mission of the organization and in particular facilities management department. The customers' contributions are their patronage, loyalty, criticisms, evaluation and feedback which are instrumental to strategic change. Then, the incisive question an inquisitive observer of Nigerian Hotels would commonly ask is: Are the traits of the GMs and FMs strong enough to drive facilities management principles and make it a huge success? This research is set to assess the traits of these cogent drivers of facilities management principles in South-Western Nigerian hotels.

\section{The Research Method}

An exploratory cross-sectional survey approach was adopted in this study devoid of control and involving one-time observation of the variables. This study covers the South-Western geo-political zone of Nigeria consisting of six States namely Lagos, Ekiti, Ogun, Oyo, Osun and Ondo with their capital city as Ikeja, Ado-Ekiti, Abeokuta, Ibadan, Oshogbo and Akure respectively as shown in Figure 5. The six States are contiguous and possess similar attributes that allowed easy comparability, improved homogeneity of the population and reduced the sampling errors. 


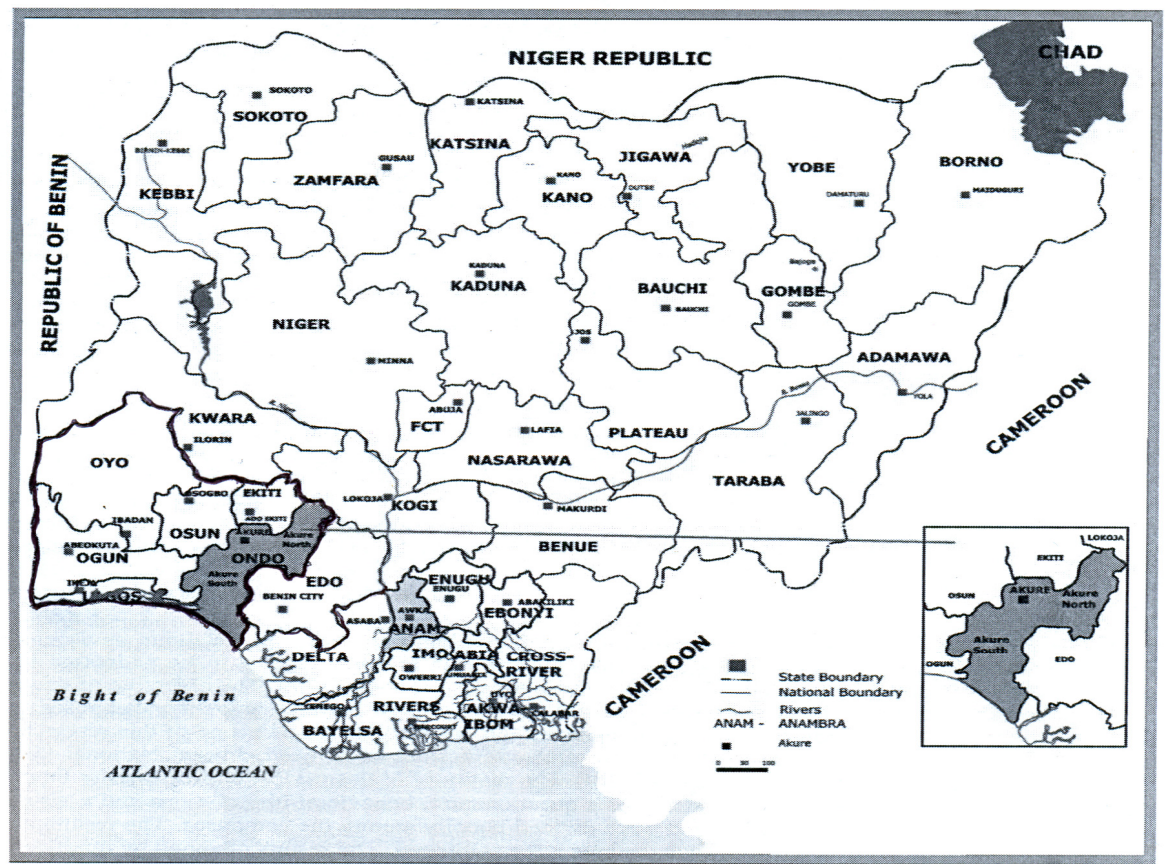

The Six Political Zones of Nigeria (States and Capitals)

\begin{tabular}{|c|c|c|c|c|c|}
\hline NORTH EAST & NORTH WEST & NORTH CENTRAL & SOUTH EAST & SOUTH WEST & SOUTH SOUTH \\
\hline ADAMAWA Yola & JIGAWA Dutse & BENUE Makurdi & ABIA Umuahia & EKITI Ado-Ekiti & AKWA-IBOM Uyo \\
\hline BAUCHI Bauchi & KADUNA Kaduna & NIGER Minna & ANAMBRA Awka & LAGOS Ikeja & BAYELSA Yenagoa \\
\hline BORNO Maiduguri & KANO Kano & KATSINA Katsina & EBONYI Abakaliki & OGUN Abeokuta & CROSS RIVER Calabar \\
\hline GOMBE Gombe & KEBBI Birni Kebbi & KOGI Lokoja & ENUGU Enugu & ONDO Akure & DELTA Asaba \\
\hline TARABA Jalingo & SOKOTO Sokoto & KWARA Ilorin & IMO Owerri & OSUN Oshogbo & EDO Benin City \\
\hline YOBE Damaturu & ZAMFARA Gusau & NASSARAWA Lafia & PLATEAU Jos & OYO Ibadan & RIVERS PortHarcourt \\
\hline
\end{tabular}

Figure 5. The study area - South-Western Geo-Political Zone of Nigeria in thick line

There are one hundred and eighty-two hotels out of which Ekiti accounted for 35 (19\%), Lagos 42 (23\%), Ogun $39(21 \%)$, Ondo $22(12 \%)$, Osun $18(10 \%)$ and Oyo $26(14 \%)$ respectively. Out of the total of one hundred and eighty-two hotels, a total of eighty hotels (44\%) were located within the State capitals. The breakdown of the hotels in the capitals indicated that Ado-Ekiti had 13 (16\%), Ikeja 29 (36\%), Abeokuta $11(14 \%)$, Akure $8(10 \%)$, Oshogbo $3(4 \%)$ and Ibadan $16(20 \%)$. The State capitals were thus selected as a result of great concentration of hotels and being the seats of governance and tourist destinations; while consideration was given to those that meet the National Classification and Grading of Hotels Standard in consonance with the policy of Nigeria Tourism Development Corporation (2001).

In determining the acceptable sample size, Kothari (1978)'s formula was adopted with confidence level set at $95 \%$ and a 0.02 probable error. By this method, the appropriate sample size of 57 was obtained and split based on the number of hotels within each State. Data collection instrument consisted of self-administered questionnaires which were administered on the hotel General Managers and Facilities Managers/Engineers/Maintenance Managers complemented with in-depth personal interview and physical survey of the constructed facilities. The questionnaires administered on the hotel General Managers/Facilities Managers were divided into three major sections namely the general information about the hotel; the general characteristics of the General Manager/Facilities Managers, and facilities management variables. Out of fifty-seven questionnaires administered on hotel management, twenty-eight (49\%) were returned.

In ensuring content validity of the questionnaires experts' opinion in environmental sciences, behavioral sciences, psychology, marketing and the hotel industry were sought on the relevance and appropriateness of the contents. Similarly, test validation was carried out on the representative of respondents on whom the test was eventually applied. In this regard, a superficial examination of the content of the instrument was carried out in order to ensure face and content validity. This was attained by testing the reliability of the instrument using the split-half 
method and a corrected coefficient of 0.76 was obtained which was considered high enough for the type of study (Glass and Stanley, 1970; Kerlinger, 1973; and Ghisell and Brown, 1978).

The dynamism and the timelessness of Covey (2004)'s paradigm and its corroboration by Drucker (1972), Odusami (2001) and Nebel and Ghei (2002) make it a ready tool of assessment for managers' traits no matter the level or the situation; hence its adoption for the assessment of the traits of facilities management key drivers in hotel organizations in South-Western Nigerian Hotels. Data were analyzed using non-parametric statistical techniques including descriptive statistics, ranking and Spearman's correlation analysis. The Spearman's correlation co-efficient is given by the formula:

$$
r=1-\frac{6 \sum d^{2}}{\mathrm{n}\left(\mathrm{n}^{2}-1\right)}
$$

where

$r=$ coefficient of rank correlation

$\mathrm{d}=$ rank difference and

$\mathrm{n}=$ number of items

The Spearman's correlation co-efficient between a pair of data is denoted by $r$ with property of

$-1 \leq \mathrm{r} \leq 1$ by which if:

$r=1$, there is perfect positive correlation

$r=0.5$, there is upward correlation in positive sense

$r=-1$, there is negative correlation

$r=0$ implies no correlation at all.

\section{Result and Discussion}

\subsection{General Characteristics of the General Managers of Studied Hotels}

Table 1 details the general characteristics of the General Managers of the participating hotels. Sixteen (16) representing $57 \%$ of the respondents were Chairmen while $12(43 \%)$ were Chairmen and Chief Executives. In terms of role classifications $5(18 \%)$ were owners of the business, $2(7 \%)$ were joint owners of the business or while $21(75 \%)$ were employees. The high employee status for the General Manager cadre could be attributed to the fact that hotel investors prefer to have managers with hotel and catering background to running the hotels themselves. Out of 28 respondents, 15 representing 54\% earn salary, $8(29 \%)$ earn salary plus profit sharing, while $5(18 \%)$ rely fully on profit sharing. In terms of age, the respondents' age brackets range from 31 years to 65 years; $11(39 \%)$ account for ages between 31 and $40 ; 10(36 \%) ; 41$ and fifty years $7(25 \%)$ were between 51 and 65 years. The high distribution of ages between 31 and 65 years might be due to the level of maturity and experience attached to the hotel managerial positions.

Out of the 28 respondents, 17 (61\%) were hotel and Catering Management practitioners; 10 (36\%) were into Business Administration; while only $1(4 \%)$ was an Accountant. Only $1(4 \%)$ of the respondents was a member of Chartered Institute of Personnel Management of Nigeria, 3 (11\%) belonged to the Nigeria Institute of Management; 18 (64\%) were members of Nigeria Hotel and Catering Management Association (NHCMA); $(21 \%)$ were members of the Nigeria Group of International Facilities Management Association. The high number of General Managers that belong to the NHCMA might be due to the desires of such people to consolidate their professional qualifications and positions in the hotel industry.

Academically, 1 (4\%) had Diploma Certificate; 1 (4\%); Full City and Guilds of London; 14 (50\%); B.A or B.Sc; 2 (8\%); Master of Philosophy; while 1 (4\%) held a Ph.D degree. The high number of degree holders as General Managers might be due to the importance attached to academic qualifications.

Regarding professional qualification, out of 28 respondents, 2 (7\%) were Honorary Members of various professional associations; 3 (11\%) were associate members; 5 (18\%) were full-fledged professional members; 17 (61\%) belonged to the Fellows cadre while $1(4 \%)$ did not indicate any professional qualification. Considering length of service in the hotel business, 20 (71\%) have been in the hotel business for the past twenty-nine years; 4 $(14 \%)$, nineteen years; while $4(14 \%)$ have acquired more than ten years work experience in the industry. In terms of overseas training, only $6(21 \%)$ have attended overseas training; while $22(79 \%)$ never had such training. The reasons given for low overseas training were high cost of such training and high mobility of labor in the industry. The tendency to engage professionally trained hotelier to manage the hotels runs contrary to Woods et al (2002)'s 
findings that the GMs considered a strongly 'business-focused' curriculum to be most valuable for a person aspiring to GM's job. However, hotel stakeholders believed that engaging 'hotelier' trained as a manager is a good starting point knowing fully well that on the job training, in-service training and experience will shape and shake the orientation of such a person for better. Woods et al (2002) established a mean age of 46 for the majority of hotel general managers. Thus, the hotels in Nigeria are not doing badly in this regard as their ages range from 31 to 50 .

Table 1. General characteristics of the chief executive/gm of studied hotels

\begin{tabular}{|c|c|c|}
\hline Characteristics & Category & Frequency $/ \%$ of Respondents \\
\hline \multirow[t]{3}{*}{ Position in Organization } & Chairman & $16(57)$ \\
\hline & Chairman \& Chief Executive & $12(43)$ \\
\hline & Total & $28(100)$ \\
\hline \multirow[t]{4}{*}{ Role Classification } & Owner of the business \& Entrepreneur & $5(18)$ \\
\hline & Joint Owner \& Entrepreneur & $2(7)$ \\
\hline & Employee & $21(75)$ \\
\hline & Total & \\
\hline \multirow[t]{4}{*}{ Method of Remuneration } & Salary & $15(54)$ \\
\hline & Salary Plus Profit sharing & $8(29)$ \\
\hline & Profit Sharing & $5(18)$ \\
\hline & Total & $28(100)$ \\
\hline \multirow[t]{5}{*}{ Age(Average) } & $<30$ & $0(0)$ \\
\hline & $31-40$ & $11(39)$ \\
\hline & $41-50$ & $10(36)$ \\
\hline & $>50$ & $7(25)$ \\
\hline & Total & $28(100)$ \\
\hline \multirow[t]{7}{*}{ Professional Calling } & Hotel \& Catering Management & $17(61)$ \\
\hline & Business Administration & $10(36)$ \\
\hline & Accounting & $1(4)$ \\
\hline & Engineering & 0 \\
\hline & No Formal Training & 0 \\
\hline & Others & $28(100)$ \\
\hline & Total & \\
\hline \multirow[t]{9}{*}{ Professional Bodies Affiliated to } & ICAN & $0(0)$ \\
\hline & CIPMN & $1(4)$ \\
\hline & NIM & $3(11)$ \\
\hline & NIQS & $0(0)$ \\
\hline & NIOB & $0(0)$ \\
\hline & NIA & $0(0)$ \\
\hline & NHCMA & $18(64)$ \\
\hline & IFMA(NG) & $6(21)$ \\
\hline & Total & $28(100)$ \\
\hline \multirow[t]{4}{*}{ Academic qualification } & Dipl. & $1(4)$ \\
\hline & OND & $0(0)$ \\
\hline & Full City \& Guilds & $1(4)$ \\
\hline & HND & $0(0)$ \\
\hline
\end{tabular}




\begin{tabular}{lll} 
& B.A/B.Sc. & $14(50)$ \\
M.Sc & M.Phil & $9(32)$ \\
& Ph.D & $2(7)$ \\
& Total & $1(4)$ \\
Professional Qualifications & Member & $28(100)$ \\
& Fellow & $8(29)$ \\
& Nil & $17(61)$ \\
Years involved in hotel business & Total & $3(11)$ \\
& $1-10$ & $28(100)$ \\
& $11-20$ & $4(14)$ \\
& $21-30$ & $4(14)$ \\
Overseas Training & $31-40$ & $20(71)$ \\
& $>40$ & $0(0)$ \\
& Yes & $28(100)$ \\
& No & $6(21)$ \\
& Total & $22(79)$ \\
\hline
\end{tabular}

Note: Institute of Chartered Accountant of Nigeria = ICAN, Chartered Institute of Personnel Management of Nigeria $=$ CIPMN, Nigerian Institute of Management $=$ NIM, Nigerian Institute of Quantity Surveyors = NIQS, Nigerian Institute of Building $=$ NIOB, Nigerian Institute of Architect $=$ NIA, Nigerian Hotel and Catering Management Association $=$ NHCMA, International Facilities Management Association (Nigeria Group) $=$ IFMA(NG).

\subsection{General Characteristics of the Facilities Managers/ Maintenance Engineers of Studied Hotels}

Table 2 shows the general characteristics of the Facilities Managers engaged by the investigated hotels. In terms of designations, out of 28 respondents $9(32 \%)$ were designated as Directors; $16(57 \%)$ as Engineers, while only 3 (11\%) were designated as Facilities Managers. The high frequency of the respondents designated as engineers might be due to the emphasis placed on Engineering Department being handled by qualified Engineers while low designation as Facilities Managers might be due to low response to facilities management principles in the sector of the economy.

In terms of age, the respondents' age range from thirty to forty years, with 17 (61\%) ageing between twenty-one and thirty years, while $11(39 \%)$ age between thirty-one and forty years. The reason adduced for low age range was due to the desire to engage relatively young engineers amenable to control and paid low wage. In respect of professional status, 16 representing 57\% were Electrical Engineers; 10 (36\%) were Mechanical Engineers; 1 (4\%) was Civil Engineer while $1(4 \%)$ did not indicate professional status. From these analyses, majority of the respondents were Electrical Engineers probably due to the belief that majority of hotel facility problems are electrical in nature.

Sixteen out of twenty-eight respondents representing 36\% were affiliated to the Nigerian Society of Engineers (NSE); 2 (7\%) to the Nigerian Institute of Building; 2 (7\%), Nigeria Group of the International Facilities Management Association; 8 (29\%) did not indicate subscription to any professional body. However, in terms of professional qualifications, 4 (14\%) were Honorary Members of their professional body; 3 (11\%), Associates Members while 21 (75\%) were Professional Members. In terms of academic qualifications, 3 representing $11 \%$ of the respondents had Ordinary Diploma Certificate; 2 (7\%) had Full City and Guilds Certificate of London; 19 (68\%) had B.A/B.Sc Degree; while 4 (14\%) had M.Sc Degree. Considering the respondents' work experience, 26 (93\%) had acquired 1 to 10 years' experience; 2 (7\%) have had 11 to 19 years; however, only $5(18 \%)$ with majority not having such training. 
Table 2. General characteristics of the facilities manager/engineers of studied hotels hotels

\begin{tabular}{|c|c|c|}
\hline Characteristics & Category & Frequency $/ \%$ of Respondents \\
\hline \multirow[t]{8}{*}{ Designation } & Director & $2(7)$ \\
\hline & Facilities Manager & $2(7)$ \\
\hline & Maintenance Manager & $3(11)$ \\
\hline & Chief Engineer & $0(0)$ \\
\hline & Engineer & $16(57)$ \\
\hline & Maintenance Officer & $5(18)$ \\
\hline & Maintenance Supervisor & $0(0)$ \\
\hline & Total & $28(100)$ \\
\hline \multirow[t]{5}{*}{ Age(Average) } & $21-30$ & $17(61)$ \\
\hline & $31-40$ & $11(39)$ \\
\hline & $41-50$ & $0(0)$ \\
\hline & $>50$ & $0(0)$ \\
\hline & Total & $28(100)$ \\
\hline \multirow[t]{9}{*}{ Professional Calling } & Mechanical & $10(36)$ \\
\hline & Electrical & $16(57)$ \\
\hline & Building & $0(0)$ \\
\hline & Civil Engineering & $1(4)$ \\
\hline & Facilities Management & $0(0)$ \\
\hline & Estate Management & $0(0)$ \\
\hline & Others & $1(4)$ \\
\hline & No Training & $0(0)$ \\
\hline & Total & \\
\hline \multirow[t]{6}{*}{ Professional Bodies Affiliated to } & NSE & $10(36)$ \\
\hline & NIOB & $2(7)$ \\
\hline & NIFMA & $2(7)$ \\
\hline & NIESV & $0(0)$ \\
\hline & Nil & $14(50)$ \\
\hline & Total & $28(100)$ \\
\hline \multirow[t]{8}{*}{ Academic qualification } & Dipl. & $0(0)$ \\
\hline & OND & $3(11)$ \\
\hline & Full City \& Guilds & $2(7)$ \\
\hline & HND & $0(0)$ \\
\hline & B.A/B.Sc. & $19(68)$ \\
\hline & M.Sc & $0(0)$ \\
\hline & M.Phil & $4(14)$ \\
\hline & Total & $28(100)$ \\
\hline \multirow[t]{4}{*}{ Professional Qualifications } & Fellow & $0(0)$ \\
\hline & Member & $12(43)$ \\
\hline & Graduate/Probationers & $16(57)$ \\
\hline & Nil & $0(0)$ \\
\hline
\end{tabular}




$\begin{array}{lll} & \text { Total } & 28(100) \\ \text { Working Experience } & 1-10 & 26(93) \\ 11-20 & 2(7) \\ 21-30 & 0(0) \\ 31-40 & 0(0) \\ 41 \& \text { above } & 0(0) \\ \text { Overseas Training } & \text { Total } & 28(100) \\ & \text { Yes } & 5(18) \\ \text { No } & 23(82) \\ & \text { Total } & 28(100)\end{array}$

Note: Nigeria Society of Engineers $=$ NSE; Nigerian Institute of Building = NIOB; International Facilities Management Association (Nigeria Group) = IFMA(NG); Nigerian Institution of Estate Surveyors and Valuers = NIESV

\subsection{Traits of the Studied Hotels' Chief Executive/General Managers}

Table 3 column 2 below shows Covey (2004)'s identified traits that an effective manager or a chief executive must possess. The Executives /General Managers of the investigated hotels were asked to assess themselves based on these traits in order of importance. These assessments were then compared in relation to Covey's proposition using the Spearman Rank Correlation analysis. Overall for the investigated hotels, a figure of 0.45 was arrived at for overall ranking which shows that the General Managers generally were below standard in terms of Covey's model. However, some of these General Managers were up to expectations and such include the General Managers for the hotels listed as 2, 3, 6, 8, 10,11,14,15, 17, 19, 22, and 24 respectively in Table 3. Out of these twelve hotels only eight belonged to the schedule of effective hotels. That implies that only five of the eleven effective hotels have General Managers that could be regarded as effective in the positive sense and that gives $45.45 \%$. The standard error of Karl Pearson's coefficient of correlation gave 0.15 . The smaller the standard error, the greater the uniformity of the sampling distribution, hence, the greater the reliability of sample. It could be concluded that the finding holds true generally for all the hotels within the study area. This result shows that hotels' operating Chief Executives were below average managerially going by Covey's model. The implication of this shortcoming is better appreciated in the light of Nebel and Ghei (2002)'s assertion as reflected in the literature.

This also implies that lack of proactive managers or chief executive would have serious repercussions on the implementation of strategic thinking within the organization generally and facilities management in particular.

Table 3. Distribution of trait parameters for the general managers

\begin{tabular}{|c|c|c|c|c|c|c|c|c|c|c|c|c|c|c|c|}
\hline & Covey's & Hotl & Hotl & Hotl & Hotl & Hotl & Hotl & Hotl & Hotl & Hotl & Hotl & Hotl & Hotl & Hotl & Hotl \\
\hline $\mathrm{S} / \mathrm{N}$ & Par & 1 & 2 & 3 & 4 & 5 & 6 & 7 & 8 & 9 & 10 & 11 & 12 & 13 & 14 \\
\hline $\mathrm{i}$ & 1 & 6 & 4 & 3 & 2 & 3 & 2 & 2 & 1 & 4 & 2 & 8 & 4 & 6 & 5 \\
\hline ii & 2 & 5 & 5 & 5 & 3 & 5 & 1 & 5 & 3 & 3 & 3 & 7 & 5 & 5 & 2 \\
\hline iii & 3 & 7 & 1 & 2 & 1 & 4 & 3 & 4 & 6 & 2 & 1 & 6 & 3 & 4 & 1 \\
\hline Iv & 4 & 4 & 2 & 4 & 7 & 6 & 4 & 3 & 10 & 1 & 6 & 5 & 2 & 3 & 6 \\
\hline $\mathrm{V}$ & 5 & 8 & 10 & 6 & 8 & 10 & 6 & 6 & 2 & 9 & 5 & 9 & 10 & 2 & 3 \\
\hline $\mathrm{Vi}$ & 6 & 3 & 3 & 7 & 9 & 1 & 5 & 10 & 4 & 10 & 4 & 4 & 9 & 1 & 4 \\
\hline Vii & 7 & 2 & 7 & 10 & 10 & 2 & 8 & 9 & 5 & 8 & 10 & 10 & 8 & 10 & 10 \\
\hline Viii & 8 & 1 & 6 & 1 & 6 & 7 & 7 & 8 & 7 & 7 & 9 & 2 & 7 & 9 & 8 \\
\hline Ix & 9 & 9 & 8 & 8 & 5 & 8 & 9 & 1 & 8 & 6 & 8 & 1 & 1 & 8 & 9 \\
\hline$X$ & 10 & 10 & 9 & 9 & 4 & 9 & 10 & 7 & 9 & 5 & 7 & 3 & 6 & 7 & 7 \\
\hline $\mathrm{R}$ & & 0.14 & 0.6 & 0.54 & 0.41 & 0.42 & 0.96 & 0.36 & 0.60 & 0.47 & 0.79 & -0.59 & 0.16 & 0.45 & 0.7 \\
\hline
\end{tabular}




\subsection{Traits of the Studied Hotels' Facilities Managers/Maintenance Managers}

Table 4 below shows the trait disposition data for the Facilities/Maintenance Managers in the investigated hotels using Covey's traits model for effective manager. Overall for the investigated hotels, Spearmans Correlation is 0.23 which means there is no perfect correlation with Covey's trait expectation. However, ten hotels have perfect correlation while six hotels have negative perfect correlation. Out of the sixteen hotels, seven that is Lagos Sheraton, Gateway Hotel, L'Eko Meridien, Excellence Hotel, Lagos Airport Hotel, Premier Hotel and MicCom Golf Hotel falls into the effective hotel category. Nonetheless, Premier Hotel displayed perfect correlation in negative sense. The standard error of Karl Pearson's coefficient of correlation gave 0.18 . The smaller the standard error, the greater the uniformity of the sampling distribution and hence the greater the reliability of sample; it can therefore be concluded that the same finding holds generally for all the hotels within the study area. This finding correlates perfectly with the finding from the earlier analysis on the GMs except that the number of proactive Maintenance Engineer or Managers in effective hotel increased to 7 out of 11 hotels; that is $64 \%$ which is above average. This is so because, as established earlier, many of the respondents are graduates with engineering background. However, it is contrary to Rutherford's disposition that responsibility for communication with employees, leadership, safety and effective organizational ability suggest that the modern hotel engineers deemed activities relating to management of their departments to be of high importance to success. Thus, one of the foremost issues facing the Chief Engineer today encompasses those that refer to managerial skills rather than the traditional view that the Chief Engineers are more concerned with the technical aspects of their jobs.

Table 4. Distribution of trait parameters for the facilities managers

\begin{tabular}{|c|c|c|c|c|c|c|c|c|c|c|c|c|c|c|c|}
\hline & Covey's & Hotl & Hotl & Hotl & Hotl & Hotl & Hotl & Hotl & Hotl & Hotl & Hotl & Hotl & Hotl & Hotl & Hotl \\
\hline $\mathrm{S} / \mathrm{N}$ & Par & 1 & 2 & 3 & 4 & 5 & 6 & 7 & 8 & 9 & 10 & 11 & 12 & 13 & 14 \\
\hline $\mathrm{i}$ & 1 & 5 & 6 & 10 & 10 & 5 & 4 & 3 & 2 & 6 & 3 & 6 & 1 & 5 & 7 \\
\hline ii & 2 & 6 & 5 & 9 & 7 & 4 & 5 & 4 & 4 & 8 & 5 & 5 & 2 & 7 & 2 \\
\hline iii & 3 & 2 & 1 & 8 & 8 & 6 & 6 & 2 & 3 & 7 & 4 & 3 & 3 & 8 & 1 \\
\hline Iv & 4 & 9 & 2 & 7 & 9 & 7 & 7 & 5 & 5 & 9 & 1 & 4 & 4 & 9 & 6 \\
\hline $\mathrm{V}$ & 5 & 10 & 4 & 2 & 4 & 10 & 9 & 1 & 7 & 10 & 10 & 2 & 5 & 6 & 3 \\
\hline $\mathrm{Vi}$ & 6 & 7 & 3 & 6 & 5 & 9 & 8 & 6 & 6 & 1 & 2 & 1 & 6 & 10 & 10 \\
\hline Vii & 7 & 8 & 10 & 1 & 6 & 8 & 10 & 10 & 9 & 2 & 7 & 10 & 10 & 3 & 9 \\
\hline Viii & 8 & 4 & 8 & 5 & 2 & 1 & 2 & 7 & 1 & 5 & 8 & 7 & 9 & 4 & 4 \\
\hline Ix & 9 & 1 & 7 & 3 & 3 & 2 & 1 & 9 & 8 & 3 & 6 & 9 & 8 & 1 & 5 \\
\hline$X$ & 10 & 3 & 9 & 4 & 1 & 3 & 3 & 8 & 10 & 4 & 9 & 8 & 7 & 2 & 8 \\
\hline $\mathrm{R}$ & & -0.3 & 0.6 & 0.76 & -0.89 & -0.33 & -0.3 & 0.76 & -0.61 & -0.56 & 0.55 & 0.5 & 0.87 & -0.62 & 0.37 \\
\hline
\end{tabular}

\begin{tabular}{cl}
\hline Key & \\
\hline Covey's & Parameter Hierarchically Arranged \\
1 & Being Proactive \\
2 & Begin with the end in mind \\
3 & Put first thins first \\
4 & Think win - win \\
5 & Seeking first to understand than to be understood \\
6 & Synergizing always \\
7 & Seeking to improve yourself always through education and training \\
8 & High intellectual ability \\
9 & Affinity for teamwork \\
10 & Enthusiastic about your working environment and related financial and legal matters. \\
& Hotl = Hotel \\
& Par = Parameter \\
& r = Spearman's coefficient of rank correlation \\
\hline
\end{tabular}


Table 4. Contd.

\begin{tabular}{ccccccccccccccc}
\hline Hotl & Hotl & Hotl & Hotl & Hotl & Hotl & Hotl & Hotl & Hotl & Hotl & Hotl & Hotl & Hotl & Hotl & O/All \\
\hline $\mathbf{1 5}$ & $\mathbf{1 6}$ & $\mathbf{1 7}$ & $\mathbf{1 8}$ & $\mathbf{1 9}$ & $\mathbf{2 0}$ & $\mathbf{2 1}$ & $\mathbf{2 2}$ & $\mathbf{2 3}$ & $\mathbf{2 4}$ & $\mathbf{2 5}$ & $\mathbf{2 6}$ & $\mathbf{2 7}$ & $\mathbf{2 8}$ & $\mathbf{R a n k g}$ \\
5 & 5 & 4 & 1 & 6 & 4 & 4 & 2 & 8 & 2 & 8 & 4 & 2 & 10 & 7 \\
6 & 3 & 5 & 2 & 7 & 9 & 3 & 5 & 10 & 5 & 10 & 17 & 4 & 3 & 5 \\
7 & 2 & 6 & 3 & 10 & 11 & 2 & 4 & 9 & 7 & 9 & 3 & 7 & 7 & 7 \\
8 & 4 & 9 & 7 & 9 & 2 & 1 & 3 & 3 & 8 & 3 & 2 & 9 & 8 & 3 \\
9 & 16 & 8 & 18 & 8 & 10 & 8 & 1 & 4 & 9 & 4 & 8 & 10 & 2 & 2 \\
10 & 1 & 7 & 9 & 5 & 3 & 9 & 6 & 2 & 6 & 2 & 1 & 8 & 9 & 4 \\
4 & 9 & 110 & 10 & 4 & 6 & 10 & 7 & 5 & 10 & 15 & 9 & 6 & 11 & 1 \\
3 & 10 & 1 & 6 & 1 & 7 & 7 & 8 & 6 & 3 & 6 & 5 & 1 & 6 & 8 \\
2 & 8 & 2 & 5 & 2 & 5 & 6 & 10 & 1 & 4 & 1 & 6 & 5 & 5 & 9 \\
1 & 7 & 3 & 4 & 3 & 8 & 15 & 19 & 17 & 1 & 7 & 10 & 3 & 4 & 6 \\
-0.58 & 0.62 & -0.32 & 0.44 & -0.76 & 0.26 & 0.5 & 0.82 & -0.5 & -0.20 & -0.50 & 0.43 & -0.15 & -0.36 & 0.23 \\
\hline
\end{tabular}

\begin{tabular}{|c|c|c|c|c|c|}
\hline \multicolumn{6}{|l|}{ Key } \\
\hline & Mainland & & Excellence & & Greenspring \\
\hline Hotel 1 & Hotel & Hotel 11 & Hotel & Hotel 21 & Hotel \\
\hline & & & Kilo & & MicCom Golf \\
\hline Hotel 2 & Federal Palace Hotel & Hotel 12 & Hotel & Hotel 22 & hotel \\
\hline & Lagos Sheraton & & Oasis & & D'Erovan \\
\hline Hotel 3 & Hotel & Hotel 13 & Hotel & Hotel 23 & Hotel \\
\hline Hotel 4 & $\begin{array}{l}\text { West End } \\
\text { Hotel }\end{array}$ & Hotel 14 & Hotel Newcastle & Hotel 24 & $\begin{array}{l}\text { Kankanfo Hotel } \\
\text { Adesba }\end{array}$ \\
\hline Hotel 5 & Olujoda Hotel & Hotel 15 & Bluenet Hotel & Hotel 25 & Hotel \\
\hline Hotel 6 & Owena Motel & Hotel 16 & Lagos Airport Hotel & Hotel 26 & K.S Motel \\
\hline Hotel 7 & $\begin{array}{l}\text { Niger Palace Hotel } \\
\text { Gateway }\end{array}$ & Hotel 17 & Lafia Hotel & Hotel 27 & $\begin{array}{l}\text { Dusmar } \\
\text { Hotel } \\
\text { Leisure Spring }\end{array}$ \\
\hline Hotel 8 & Hotel & Hotel 18 & Heritage Hotel & Hotel 28 & Hotel \\
\hline Hotel 9 & Hotel Plaza & Hotel 19 & Premier Hotel & & \\
\hline Hotel 10 & $\begin{array}{l}\text { L'Eko } \\
\text { meridien }\end{array}$ & Hotel 20 & Universal Hotel & \multirow{2}{*}{\multicolumn{2}{|c|}{$\begin{array}{l}r=\text { Spearman Correlation } \\
\text { Co - efficient. } 0.5 \text { and above is } \\
\text { taken to mean perfect correlation. } \\
\text { Pr implies Parameter }\end{array}$}} \\
\hline \multicolumn{2}{|l|}{ Hotl $=$ Hotel } & \multicolumn{2}{|c|}{$\begin{array}{l}\mathrm{O} / \mathrm{All}=\text { Overall } \\
\text { Rankg = Ranking }\end{array}$} & & \\
\hline
\end{tabular}

\section{Conclusion and Recommendations}

The GMs background, training and features in South-Western Nigerian hotels cannot be said to be poor or low in that they compared favorably with the standard in advanced countries, particularly United State of America; however, they lack international exposure. In terms of traits, using Covey's proposition as benchmark, the GMs are below average managerially, lacking the dynamism and the pizzazz that are required to propel them along. Lack of proactive managers would have serious repercussions on the implementation of facilities management as instrument of strategic and sustainable development.

The same traits were exhibited by the Facilities Managers/Maintenance Managers/Chief Engineers and being the ones directly involved in facilities management implementation strategy implies that the objectives of the facilities management may be extremely hampered from being achieved. In essence, the exposure of the GMS and the FMs must be deliberately improved upon while the duo must, as a matter of urgency, cultivate the habit of learning how to be effective in accordance with Drucker (1972)'s proposition and Covey (2004)'s suggestion.

\section{References}

Adewunmi, Y., \& Ogunba, O. (2006). Shaping a Sustainable Role for Estate Surveyors and Valuers in the Evolution of Facilities Management in Nigeria. International Conference on the Built Environment, 
Innovation Policy and Sustainable Development Covenant University Ota, Nigeria, 322 - 327.

Arditi, D., \& Nawakorawit, M. (1999). Issues in Building Maintenance: Property Managers' Perspective. Journal of Architectural Engineering, 117-132. http://dx.doi.org/10.1061/(ASCE)1076-0431(1999)5:4(117)

Asika, N. (1991). Research Methodology in the Behavioral Sciences (1st ed.). Lagos: Longman Nigeria Plc.

Conklin, M. (2002). As I See It: Hotel Organization Structure. In Rutherford, D. G. (Ed.), Hotel Management and Operations (3rd ed.) (pp 53-54). New York John Wiley \& Sons, Inc.

Covey, S. (2004). The 7 Habits of Highly Effective People (1st ed.). London: Simon and Schuster Uk Ltd.

Drucker, P. (1972). The Effective Executive (3rd ed.). London: William Heinemann Ltd.

Durodola, O. D., \& Oloyede, S. A. (2011). Empirical Determination of Property Assets Management Styles in South-Western Nigeria Hotels. Journal of Sustainable Development, 4(1), 151-159.

Durodola, O. D., Ajayi, C. A., \& Oloyede, S. A. (2011). Impact of Property Assets' Management Styles on Effective Service Delivery in South-Western Nigeria Hotels. Journal of Sustainable Development, 4(4), 151-159. http://dx.doi.org/10.5539/jsd.v4n4p116

Eddystone, C., \& Nebel, III. (2002). Organization Design. In Rutherford, D. G. (Ed.), Hotel Management and Operations (3rd ed.) (pp. 41-52). New York: John Wiley \& Sons, Inc.

Ghiselli, E. E., \& Brown, C. W. (1978). Personnel and Industrial Psychology (1st ed.). New York: McGraw-Hill.

Glass, G. V., \& Stanley, J. C. (1970). Statistical Methods in Education and Psychology (2nd ed.). New Jersey: Prentice-Hall.

Hassanain, M. A, Froese, T. M, Asce, M., \& Vanier, D. J. (2003). Framework Model for Asset Maintenance Management. Journal of Performance of Constructed Facilities, February, $51 \quad-\quad 64$. http://dx.doi.org/10.1061/(ASCE)0887-3828(2003)17:1(51)

Hayes, D. K., \& Ninemeier, J. D. (2007). Hotel Operations Management (2nd ed.). New Jersey: Pearson Prince Hall.

Kerlinger, F. N. (1973). Foundations of Behavioral Research. London: Holt, Rinehart and Winston.

Kothari, C. R. (1978). Quantitative Techniques (3rd ed.). New Delhi: Vikas Publishing House PVT Ltd.

Mintzberg, H. (1075). The Manager's Job: Folklore and Facts. Harvard Business Review, July - August, 49 - 61.

Nebel, E. C., \& Ghei, A. (2002). A Conceptual Framework of the Hotel General Manager's Job. In Rutherford, D. G. (Ed.), Hotel Management and Operations (3rd ed.) (pp. 55 - 63). New York: John Wiley \& Sons, Inc.

Nigerian Tourism Development Corporation (NTDC). (2001). Standard for National Classification and Grading of Hotels and Other Serviced Accommodations in Nigeria (1st ed.). Abuja: Nigerian Tourism Development Corporation.

Odusami, K. (2001). Project Team Leadership and Construction Project Performance in Some Selected States of Nigeria. Unpublished Ph.D Thesis of the Department of Building, University of Lagos, Akoka, Lagos.

Opaluwah, S. A. (2005). Principles and Practice of Facilities Management in Nigeria. Abuja: Still Waters Publications.

Owen, D. (1995). FM is not Just a Radio Station. Chartered Surveyor Monthly, Supplement, June, II - IV.

Rutherford, D. G. (2002). As I See It: Organization Structure. In Rutherford, D. G. (Ed.), Hotel Management and Operations (3rd ed.) (pp. 55-63). New York: John Wiley \& Sons, Inc.

Smith, S. (2003). Defining Facilities. In Rick, B., Langston, G., \& Gerard de V. (Eds.), Workplace Strategies and Facilities Managements (1st ed.) (pp. 11-27). Burlington: Butterworth-Heinemann Publications.

Torkildsen, G. (1992). Leisure Recreation Management (3rd ed.). London: E \& FN Spon.

Woods, R.H., Rutherford, D.G., Schmidgall \& Sciarini. (2002). Hotel General Managers: Focussed on the Core Business. In Rutherford, D. G. (Ed.), Hotel Management and Operations (3rd ed.) (pp. 55-63). New York: John Wiley \& Sons, Inc. 